\title{
Spatial Analysis of Deforestation and Its Impact on Carbon Emissions Using FREL
}

\author{
Mujiono \\ Masters student in Geography, FMIPA UI, \\ Depok, 16424, Indonesia \\ Coresponding email: mjion38@yahoo.com \\ Tito Latif Indra \\ Lecturer in the Department of Geography FMIPA UI \\ Depok, 16424, Indonesia \\ Djoko Harmantyo \\ Lecturer in the Department of Geography FMIPA UI \\ Depok, 16424, Indonesia
}

\begin{abstract}
The research aimed to analyze spatial patterns of deforestation in 1996, 2007, and 2016, and estimated carbon emission in the forest sector, both production forests, protected forests, and conservation forests in Bengkulu Utara district. Methods of spatial analysis change used land change modeller (LCM) while Forest Reference Emissions Level (FREL) was used as a reference in calculating carbon emissions. The analysis showed that deforestation in Bengkulu Utara district had caused a reduction in forest area of 24.965 ha $(12 \%)$. The deforestation rate was much higher in the period $1996-2007$. The conversion of forests in this area was quite alarming because an 8-fold was much higher than the deforestation in the district of Toba Samosir area of 3.002 ha and was not much different from the area of deforestation that occurred in the two districts at a time that the Konawe Utara district and Konawe district with an area of 54.583 ha. Deforestation had caused the loss of an area of 18 . 266 ha of production forests, protected forests 5.290 ha and $\mathbf{1 . 4 0 1}$ ha of forest conservation. Plantation and open land encroachment was a major factor in the region. In a period of 20 years, the forest sector had accounted Bengkulu Utara carbon emissions by 614.889 ton. Look at the facts, the local government should make an effort to pressure the higher the rate of deforestation. Efforts can be made by means of changes in the concept of development of the land sector to other sectors (eg. education and small and medium enterprises), using the RTRW as the basic framework of development and FREL as a reference in calculating carbon emissions.
\end{abstract}

Keywords-Deforestation, land cover, FREL, carbon emissions

\section{INTRODUCTION}

Bengkulu Utara is one of the districts in the capital of Bengkulu province Arga Makmur. The astronomical district is located between $3^{\circ} 11^{\prime} 07$ "S - 101 ${ }^{\circ} 59^{\prime} 54^{\prime \prime} \mathrm{E}$ and consists of the mainland and the island (Enggano Island). Many activities on land (e.g. plantations and mines) and limited physical space raise the insistence on natural spaces like the woods. Economic instability, political, legal basis and regional characteristics influence people's behavior in a plan, make decisions and act include land conversion from forest to open land, from the rice fields into palm oil plantations, from agriculture into smaller plots and so on. Expansion of land clearing for agriculture, mining and plantations increased when investors participate in the control and manage land. Things are bad when people do not feel the benefits and are faced with the problem of poverty, health, pollution, land conflicts, human-animal conflict, lack of infrastructure and so forth. This situation has also become the people's choice to remain or move.

In the era of regional autonomy, forest resources are often used as objects in promoting economic growth so that its presence tends to stress a very serious form of deforestation and accounted for 18 percent of emissions by 42 Gton $\mathrm{CO}_{2} \mathrm{e}$ per year (Suharto, 2011; Stern, 2007). There should be many economic benefits derived deforested country, but these benefits have not been evenly distributed, and some of the biggest cost has not been calculated. The costs include costs for food security, energy, health and water. Many studies estimate the economics of ecosystem services lost due to deforestation could reach the US $\$ 2$ to 4 billion per year (Rautner et al, 2013).

Deforestation is also driven by not optimal sustainable forest management systems such as the uncertainty and lack of definition of forest and forest boundaries contained in several regulations such as Law No. 41/1999 on Forestry, Government Regulation No. 44/2004 on Forestry Plan, Minister of Forestry Regulation on Standards and Criteria an area is called the Forest Zone, and Forestry Minister Regulation No. 50/2009 on the Status and Function of Forest Area. Even the appearance of the different interests of forest areas between the central government, local government and community protracted conflict (Angi, 2005). 
The political, social and legal as described previously is deforestation in the perspective of time. While the spatial perfective deforestation can be explained in the aspect of the location, area, distance, connectivity, and other spatial elements (wijaya, 2015). This means that the physical characteristics of the area such as slope and class elevation, distance from the road, distance from the river, the distance from the plantation and the distance of the settlement have a significant impact on deforestation (Prasetyo et al, 2009; Arekhi \& Jafarzadeh, 2012; Wyman \& Stein, 2010; Kumar et al, 2014). In addition, coal also participated trigger deforestation (Fiyanto et al, 2010). The point of physical factors is fundamental determinants of the rate of change in land use (Xiangmei et al, 2016).

Based on data from the Directorate of Forest Resources Inventory and Monitoring - The Ministry of Environment and Forests, Bengkulu province has the highest deforestation rate in Indonesia in the function of protected forest reaches 6000.7 ha/year, while the highest deforestation on the forest conservation is second $(2.775 \mathrm{ha} /$ year $)$ after the province of Riau, while deforestation in production forests Bengkulu ranks third and second with details of $393.8 \mathrm{ha} / \mathrm{yr}$ (permanent production forests) and $2922.8 \mathrm{ha} / \mathrm{yr}$ (limited production) (Director of Forest Resources Inventory and Monitoring, 20132014). From 2010 to 2015, Bengkulu Utara is able to increase the Gross Domestic Product (GDP) from the forest, fisheries and agriculture amounted to 4, 74 percent or about Rp. 5. 735 889, 6 (Central Berau of Statistics North Bengkulu, 2016). The amount of revenue from the forest sector is increasingly concerned about the existence of this area of forest in a sustainable manner.

The high rate of deforestation made Bengkulu Utara as the highest emissions contributor all at once as the project target reduction in greenhouse gas emissions set by the Governor Regulation No. 30 of 2012 which is a derivative of the Presidential Regulation No. 61 Year 2011 on National Action Plan for the Reduction of Emissions of Greenhouse Gases. The plan is a priority because of deforestation of tropical regions recognized as one of the most critical environmental issues with social and economic consequences as well as the longterm causes of global warming, the destruction of the water cycle, and reduced biodiversity (Boonyanuphap, 2004; Carren \& Fearnside, 2011).

Recognizing the importance of the role of forests in the long-term development in the economic, social and environmental, including its role in climate change mitigation. Then reduce deforestation commitment can not be separated from geospatial information (GI) in the field. Spatial analysis is an important step to get geospatial information in two dimensions (space and time) as well as answer the questions, what? Where? and when it happens?. The use of remote sensing technology can provide basic information for managing the protection, preservation and production of forest land in a sustainable manner (Nurmiaty, 2014; Vazquez, 2016). While use Forest References Emission Level (FREL) will be the basis of assessing the success of Bengkulu Utara in reducing greenhouse gas emissions (GHG) from the forest sector. Therefore, to determine the Geospatial Information (GI), the deforestation and the amount of carbon dioxide $\left(\mathrm{CO}_{2}\right)$, the formulation of research problems are:

- How do spatial analysis of deforestation in Bengkulu Utara District?

- How much carbon dioxide emission $\left(\mathrm{CO}_{2}\right)$ in the forest sector in Bengkulu Utara?

\section{METHOD}

\section{A. Research Approach}

The research used quantitative descriptive approach by measurable, reportable and verifiable.The approach was done by calculating the area and land cover transitions in certain periods and made a massive matrix of carbon dioxide $\left(\mathrm{CO}_{2}\right)$ in each forest.

\section{B. Sample Area}

The area that became the object of the study was in Bengkulu Utara district with an analysis unit of forest area; conservation (SK : No. 863 / Menhut-II / 2014), protected and production (No. 784 / Menhut-II / 2012). Area of other land use was not used in the analysis because it was not considered as cultivation area / non forest.

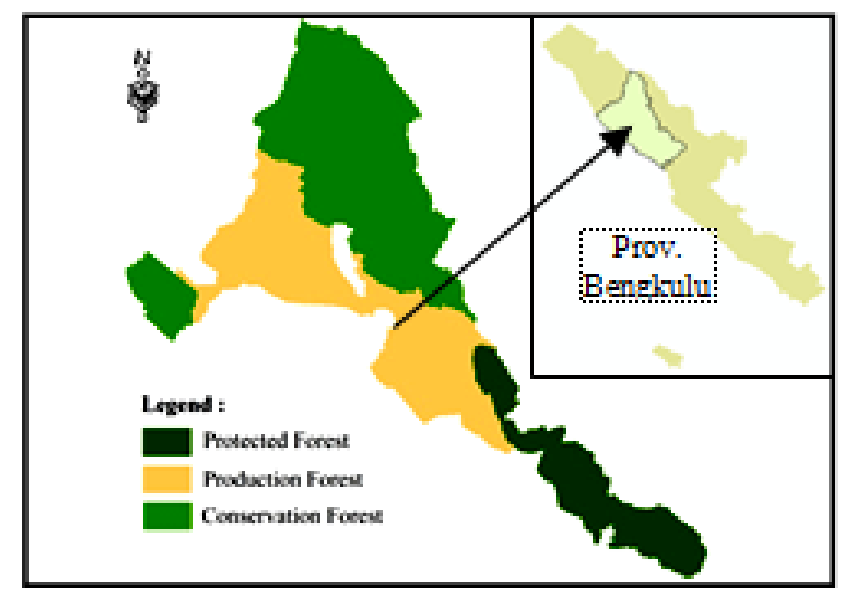

Fig. 1. Map of the Forest Zone Bengkulu Utara District

While the sample used was the area of land use in the validation test using Matrix Ground Truth ROI (Region of Interest). In the process of land cover mapping accuracy could be accepted or considered valid if it exceeds Kappa coeffisien $\geq$ 85\% [18]. Kappa coefficient consider all aspects of the accuracy of the manufacturer and user accuracy. Producer accuracy value served as a thematic assessment, which showed the classification of the degree of truth of the situation. While the accuracy of the classification accuracy explaining the whole object identified (Ardiansyah, 2015).

\section{Conceptual Frame Work}

The quality of a study could not be separated from framework or concept. In general, in the framework of stacking based on problems arise, facts on the field, and the method used with reference to the formulation of the problem. 


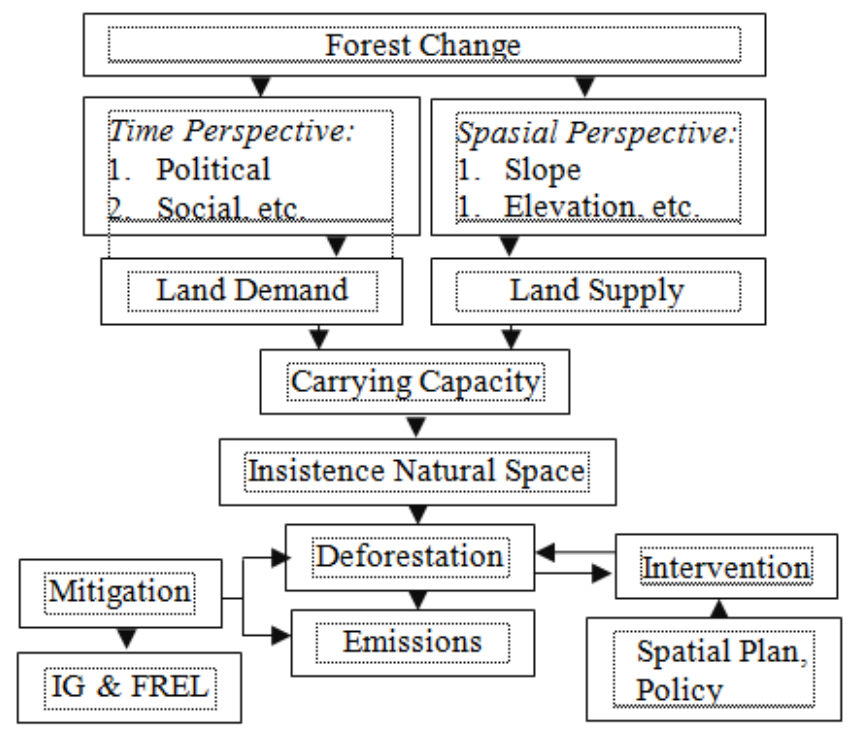

Fig. 2. Conceptual Framework

\section{Research Procedure}

The procedure includes all forms of technical research began with the processing of Landsat Thematic Mapper 5 (1997 and 2007) and Landsat Thematic Mapper 8 (2016) Path 126 Row 62 with the following scheme:

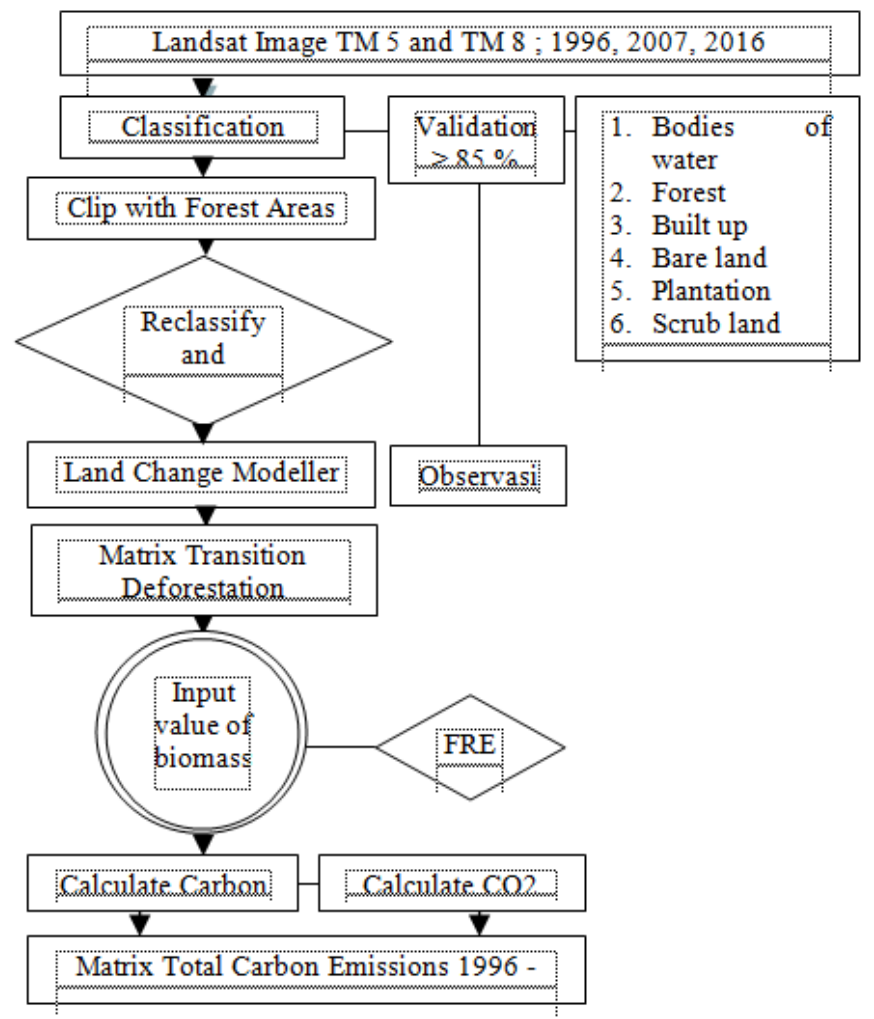

Fig. 3. Research Procedure

\section{E. Data Analysis}

Broadly speaking, the data processing consists of three main parts: image processing, land change modeller and the transition matrix using Forest Reference Emissions Level. The imagery used to be a Landsat image with recording in 1996, 2007 and 2016. The year was selected on the following basis:

1996 - $70 \%$ farmer has cleared the land since 1996 and continued to increase significantly during the crisis in 1998-1999 (GFW, 2001).

- Since 1996, deforestation appears to have increased again to about 2 million ha per year, (Director of Forest Resources Inventory and Monitoring, 2013 2014).

- 7 million ha have been approved and converted to orchid till the end of 1997, (Director of Forest Resources Inventory and Monitoring, 2013-2014).

- Highest Deforestation in Indonesia occurred in the period 1996 - 2000, (Director of Forest Resources Inventory and Monitoring, 2013-2014).

- The book of State of the World's Forest FAO stated that the rate of deforestation in Indonesia reached 1.87 million ha, (Purba et al, 2014).

- 2004-2006 forest cover of the entire territory of Indonesia was reduced to 83 million ha (Narendra, 2008).

2016 • 2016 deforestation in Indonesia was still dominant in the three-quarters of cases recorded; while the remaining concerned on social issues, (Wakker, 2016).

The details of the stages are as follows:

- Image Processing, data used in accordance with the above. Land use classification refers BAPLAN 2001 guidelines further generalized into seven classes namely; bodies of water, forest, built-up, bare land, plantation, scrub land, rice field. While cloud cover and cloud shadows do reclassify stages and geoprocessing based on high-resolution imagery or nearby land use.

- Land change modeller, a simple analysis was used to analyze the effect on any type of land use on deforestation along with its area using IDRISI Selva version 17.

- Matrix transition, at this stage of the calculation using the Forest Reference Level Emission in 2015 (Indrawan, 2012) with a value of biomass as follows.

TABLE I. BIOMASS VALUE ON FREL 2015

\begin{tabular}{|l|l|l|}
\hline Land Cover & Biomass & Source \\
\hline Forest & 365,1 & NFI \\
\hline Built up & 11 & NFI \\
\hline Bare land* & 14 & LITBANG KLHK \\
\hline Plantation & 81 & NFI \\
\hline Scrub land & 34,5 & Wasrin, 2000 \\
\hline Paddy field & 5 & NFI \\
\hline
\end{tabular}


After entering data into the field of biomass, then the next step was to calculate the carbon $(\mathrm{C})$, carbon dioxide $\left(\mathrm{CO}_{2}\right)$ and total emissions by the following formula.

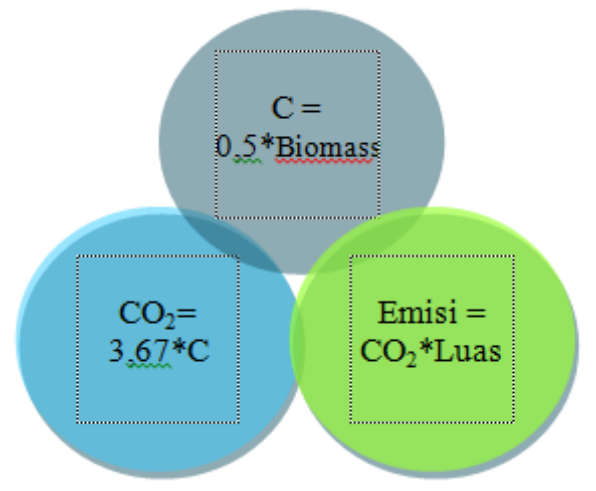

\section{FINDING AND DISCUSSION}

\section{A. Land Cover and Transition Change}

The accuracy of test results using high-resolution imagery (World View) in 2016 with the method ROI Confusion Matrix Ground Truth was in $89,5 \%$. The seven classes of land cover classification and transition deforestation are shown in the map and table below.

Fig. 4. Emission Calculation Formula

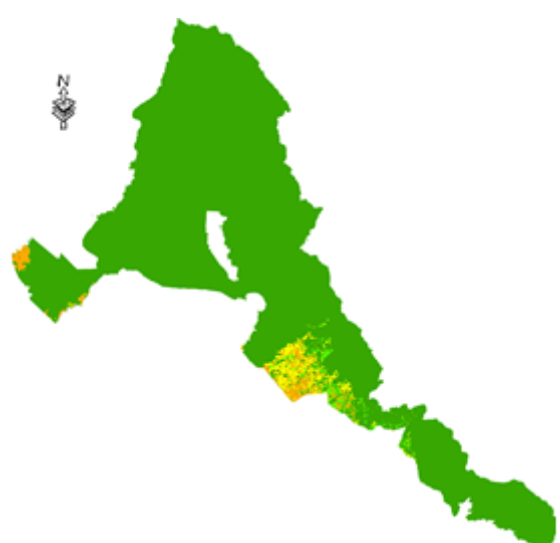

1996

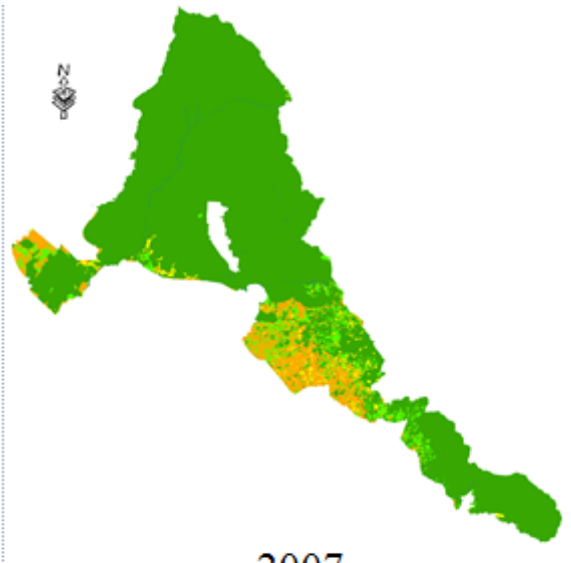

2007

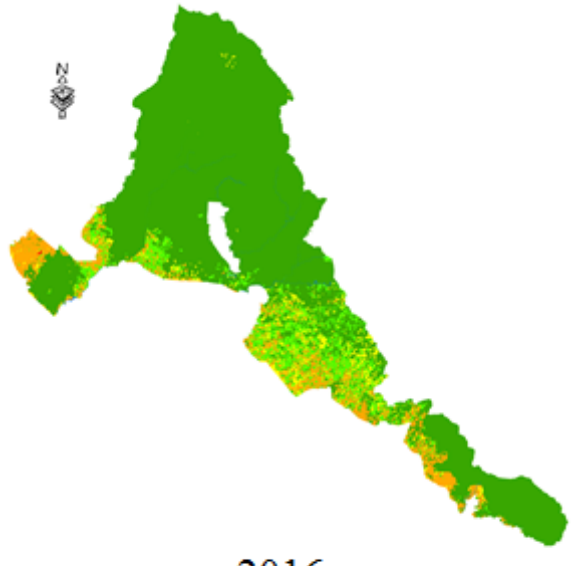

2016

\section{Legend \\ Fig. 5. Land Cover on Forest Areas by Function}

\section{B. Deforestation}

The forest area in Bengkulu Utara district experienced a significant intervention. The availability increasingly limited due to the increasing needs and society's dependence on the sector for the land, used for plantation, farming and even mining. In the period 1996 - 2007 Bengkulu Utara encroachment occurred massively with a total area of 14.152 hectares of forest loss. Meanwhile, in the period 2007 - 2016 of encroachment tended to decrease with the number of 10.813 hectares. This was caused by the limited physical aspects e. g. increasing altitude and slope so that the region becomes difficult to try. Until 2016, deforestation in Bengkulu Utara has reached $12 \%$ or 24.965 hectares.

Deforestation with an area 24.965 ha could not be said to be slightly because the rate is eight times much higher than the deforestation in the district of Toba Samosir covering an area of 3.002 ha (Silitonga, 2011) and was not much different from the area of deforestation that occurred in the two districts at a time that district of Konawe Utara and district of Konawe District with an area of 54.583 hectares (Setiawan, 2015). Deforestation will continue if no serious efforts from the government. Encroachment will continue to occur with many factors both, physical and social community. Here was a decrease in forest area in the district of Bengkulu Utara.

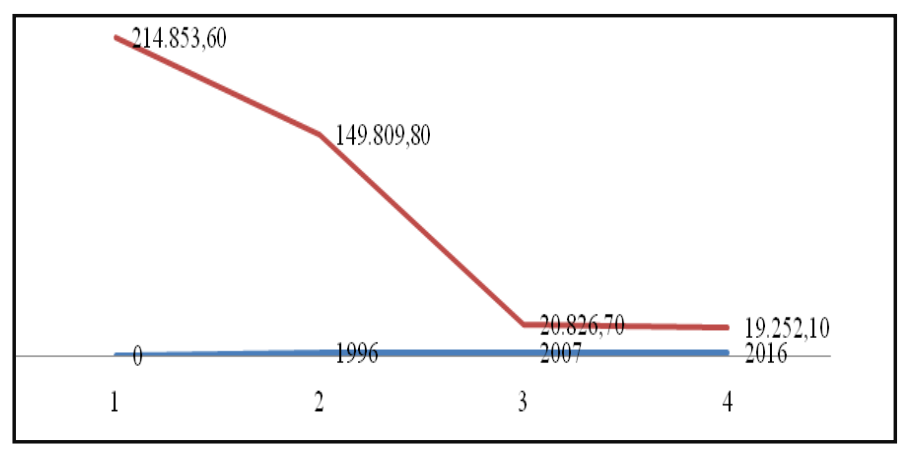


Fig. 6. Changes in Forest Cover1996 to 2016

At first, Bengkulu Utara had a forest area with a total area of \pm 214.854 hectares. But the number of activities outside the forest sector made forests were reduced and changed to another use. Changes dominated by plantations, open land (new land clearing) and shrubs as a result of shifting cultivation into fallow. The figure below shows the percentage of land cover in the forest area in each year.

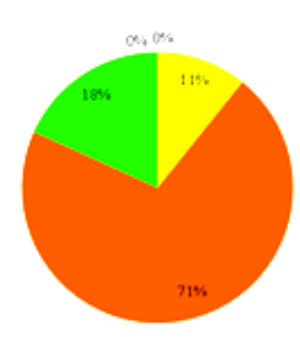

(1996)

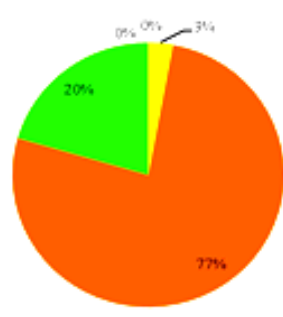

(2007)

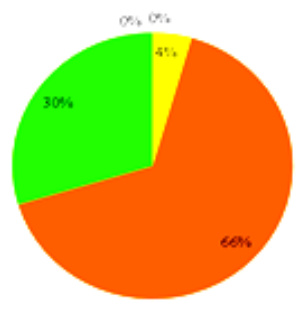

(2016)
Fig. 7. Percentage of Land cover Drivers of Deforestation

TABLE II. DEFORESTATION FOREST AREA (ha) 2016

\begin{tabular}{|l|r|r|r|}
\hline Land Cover & Prod. Forest & Prot. Forest & \multicolumn{1}{l|}{ Kons. Forest } \\
\hline Bodies of water & 161,05 & 27,74 & 180,32 \\
\hline Built up & 2,23 & 1,76 & 22,19 \\
\hline Bare land & $3.464,98$ & $1.479,84$ & 215,05 \\
\hline Plantation & $7.188,3$ & $1.588,88$ & 744,62 \\
\hline Scrub land & $7.449,12$ & $2.185,73$ & 246,91 \\
\hline Rice field & 0,18 & 5,78 & 0 \\
\hline Sub total & $18.265,86$ & $5.289,73$ & $1.409,09$ \\
\hline Tot. Deforestation & \multicolumn{3}{|l}{24.965} \\
\hline
\end{tabular}

Based on the interpretation of Landsat 2016 describes that forest areas most deforested is a producing forest area of 18 266 hectares of fact, though said to be production forests, should the local government still provides the limitations ranging from selective logging, license utilization, emphasis ecological aspects and so on, Berjalanya But over time, encroachment in the region getting out of control and are beyond the understanding even the real plan. The following table is deforestation in each forest.

The body of water though, as the natural land cover yet the changes were highly dependent on the upstream region. If the damage occurred in upstream then directly or indirectly would create new landforms like an oxbow lake. Besides the changes that occurred in the upstream would lead to run-off so that the volume of water during a flood would rise dramatically and was eroding the riverbanks. As a result, water bodies became widespread than before. Therefore, the water body could not be separated on aspects of change land/forest, but not the aspect of carbon emissions.

\section{Carbon Emissions}

Carbon emissions from the forest sector was a major problem of developing countries. Unlike the developed countries that have a lot of emissions from the industrial sector. In general, developing countries still depended their life on the land sector and always made efforts to achieve economic stability by increasing the license of the mining business to reproducing plantation expansion. Realized or not, this was precisely the act of sacrificing environmental aspects such as climate change in the long term.

In a period of 20 years, the forest sector in Bengkulu Utara district had accounted carbon emissions by 614.889 tons of $\mathrm{CO}_{2}$ in the air. Open land and scrub from land clearing was a major trigger of Greenhouse Gases in Bengkulu Utara that occurred in the period 1996 - 2007 with a total emission of 272.895 tons. Here is a summary of emissions using pivot tables.

TABLE III. MATRIX EMISSIONS FROM 1996 - 2016

\begin{tabular}{|c|r|r|r|r|r|}
\hline Land Cover & \multicolumn{1}{|c|}{ BU } & \multicolumn{1}{c|}{ BL } & \multicolumn{1}{c|}{ PL } & \multicolumn{1}{c|}{ SL } & \multicolumn{1}{c|}{ Total } \\
\hline BU & & 880 & 1.383 & 1.400 & 3.663 \\
\hline BL & 161 & 4.108 & 205.951 & 62.675 & 272.895 \\
\hline PL & & 56.995 & 177.493 & 10.616 & 245.104 \\
\hline SL & 50 & 7.139 & 62.772 & 23.251 & 93.212 \\
\hline PF & - & - & 15 & - & 15 \\
\hline Total & 211 & 69.122 & 447.614 & 97.942 & $\mathbf{6 1 4 . 8 8 9}$ \\
\hline
\end{tabular}

The amount of emissions released from the forest sector in Bengkulu Utara was a basic and meaningful participation in climate change mitigation measures. This condition became more significant when emissions from the land use change sector be included in the calculation.

\section{CONCLUSIONS AND SUGGESTIONS}

\section{A. Conclusions}

Geospatial information is a concept which is indispensable in efforts to reduce the rate of forest clearing continues to occur because of economic instability, political, legal basis even physical character of the area itself. Commitment to mitigate climate change should be a priority and responsibility of local governments on decentralization. Forest Reference Emissions Level (FREL) is a testament to the country's sovereignty at the same frame of reference that can be used in mitigating climate change in 2020 and subsequent years.

Still, Bengkulu Utara economic dependency on the land sector (e. g. plantations and mines) caused so much activity on the ground, causing the insistence on the form of natural space limit deforestation. Intervention in the forestry sector from 1996 to 2016 has led to the loss of forest area of 24.965 ha or $12 \%$ of the total forest area is \pm 214.854 hectares.

Deforestation occurs in many production forests with a total area of 18.266 ha. These conditions have an impact on climate change. Until now, Bengkulu Utara has been producing carbon dioxide $\left(\mathrm{CO}_{2}\right)$ emissions by 614.889 tons. Plantations and open land is a major factor in deforestation and carbon emissions in both production forests, protection and conservation. 


\section{B. Suggestions}

Responsibility and action is taken in order to achieve sustainable development (physical, social and economic). Efforts to reduce deforestation and carbon emissions can be done in the following ways:

- Changing the concept of development of the land sector to sector of human development, such as education and raise public sector of Small and Medium Enterprises.

- Using Reference RTRW (spatial plan) in development activities and integrated with the plan of the province, the central government as well as across sectors.

- Using Forest Reference Emissions Level in mitigating climate change as a form of state sovereignty.

\section{ACKNOWLEDGMENT}

Thanks to Dr. Djoko Harmantyo, M. S. and Dr. Tito Latif Indra, S. Si., M. Si. As a mentor in completing this paper. Thanks to government agencies such as KLHK RI, LAPAN and BIG in providing accurate data. Hopefully this paper can be useful for further studies.

\section{REFERENCES}

[1] Anderson, J. R, et al, (1976), "A Land Use and Land Cover Classification System For Use With Remote Sensor Data", Geologica Survey Profesional Paper 964, Washington: US Goverment Printing Office.

[2] Angi M., E, (2005), "Central Government Policy in the Field of Conservation from the Perspective of Regional and Communit", West Bogor, Center For International Forest Research, (Chapter 1).

[3] Ardiansyah, (2015), "Remote Sensing Image Processing Using the ENVI5. 1 and ENVI LiDAR (Theory and Practice)", Jakarta: LAB SIG INDERAJA, (Chapter 8).

[4] Arekhi S, \& Jafarzadeh, 2012, "Deforestation modeling using logistic regression and GIS (Case study: Northern Ilam forest, Ilam Province, Iran)", AfricanJournal of Agricultural Research, 7, 1727-1741.

[5] Boonyanuphap, J, (2004), "Spatial Model For Determining Risk Area Of Deforestation”, Suranaree Journal Science Technology, 12, 145-159.

[6] Carrero, G. C., and P. M. Fearnside, (2011), "Forest clearing dynamics and the expansion of landholdings in Apuí, a deforestation hotspot on Brazil's Transamazon Highway". Ecology and Society, 16(2), 26.

[7] Central Bureau Of Statistics North Bengkulu, (2016), "North Bengkulu Regency in Figures (Regional Income)", (Chapter 12).

[8] Directorate Of Forest Resources Inventory And Monitoring, (2015), "DeforestationIndonesiaYear 2013 - 2014", Jakarta: Ministry of Environment and Forestry, (Chapter 3).
[9] Fiyanto, A., Mulaika, A., Hidayati, N.,Shahab, N., Guerrero, L, (2010), "Batubara Mematikan", Jakarta, Greenpeace Asia Tenggara dan Walhi, (Bab 1).

[10] Indrawan, S, (2012), "Technical Guidelines For Calculation Of Reference Level Emission Sector Based On Land", Jakarta: UNREDD+ Programme Indonesia, (Chapter 6).

[11] Kumar R, Nandy S, Agarwal R, Kushwaha SPS, 2014, "Forest cover dynamics analysis and prediction modeling using logistic regression model. Ecological Indicators", 45, 444-455.

[12] Narendra, B.H, (2008), "Transfer Function (Conversion) Forest Zone Indonesia: Overview Aspects of Hydrology and Soil Conservation", Proceeding Function Fiorest Area, pp. 103-117.

[13] Nurmiaty, "GIS-Based Modelling of Land Use Dynamics Using Cellular Automata and Markov Chain", Journal of Environment and Earth Science, Vol. 4 (4), 61 - 66 (2014).

[14] Prasetyo, LB, Kartodiharjo H, Adiwibowo S, Okarda B, Setiawan Y, 2009, "Spatial Model Approach on Deforestation of Java Island, Indonesia", Journal of Integrated Field Science, 6, 37- 44.

[15] Purba, C. P. P. Et al, (2014), "Portrait Of State Forest IndonesiaPeriod 2009-2013", Bogor: FWI, (Chapter 2).

[16] Rautner, M., Leggett, M., Davis, F., 2013, "Small Book Pusher Large Deforestation", Global Canopy Programme: Oxford.

[17] Setiawan, H, (2015), "Spatial Model DeforestationIn North Konawe and Southeast Konawe Sulawesi Province", Thesis, Graduate School, IPB, (Chapter 4)

[18] Silitonga, P, (2011), "Analysis Of Spatial Degradation and Deforestation AreaForest For Planning The Use Of SpaceIn The District Toba Samosir", Thesis, Graduate School, USU, (Chapter 4)

[19] Stern, N, 2007, "The Stern Review: The Economics of Climate Change", Cambridge:Cambridge University Press.

[20] Suharto, R. B, (2011), "Reconstruction Bureaucracy Local Government Natural Resource Management Towards Sustainability Ecology", Thesis, GraduateSchool UNDIP, (Chapter 1).

[21] Vázquez-Quintero, Griselda, Detection and Projection of Forest Change by Using the Markov Chain Model and Cellular Automata, Journal mdpi. Vol. 8 (236), 6 - 9, (2016).

[22] Wakker, E, (2016), "Impact Of Policy Zero Deforestation", Bogor: Eidenvironment.

[23] Wijaya.P. A, (2015), "Spatial Model Deforestation in Jambi Province", Theses, Graduate School, IPB, (Chapter 4).

[24] World Resource FWI/GFW, 2001, "State of the Forest Indonesia", Bogor , Indonesia: Forest Watch Indonesia dan Washington D.C. Global Forest Watch, (Chapter 3).

[25] Wyman MS \& Stein TV, 2010, "Modelling social and land-use/landcover change data to assess drivers of smallholder deforestation in Belize", Applied Geography, 30, 329-342.

[26] Xiangmei, Li. et. Al, (2016), "Physical and Socioeconomic Driving Forces of Land-Use and Land-Cover Changes: A Case Study of Wuhan City, China", Discrete Dynamics in Nature and Society, 2016, 1 - 11. http://dx.doi.org/10.1155/2016/8061069. 